\title{
PENGARUH LATIHAN TENDANGAN KAKI BAGIAN LUAR DAN LATIHAN TENDANGAN KAKI BAGIAN DALAM TERHADAP AKURASI TENDANGAN BEBAS 30 METER
}

\author{
Anggi Anggara 1), dan Rahmat ${ }^{2}$ ) \\ 1 Universitas Islam Al-Ihya Kuningan \\ 2 Universitas Islam Al-Ihya Kuningan \\ e-mail: anggianggara2701@gmail.com ${ }^{1}$,rahmat.aj75@yahoo.com²
}

\begin{abstract}
Abstrak
Tujuan latihan tendangan kaki bagian luar dan tendangan kaki bagian dalam terhadap akurasi tendangan bebas 30 meter untuk mengetahui seberapa besar pengaruhnya dan seberapa baiknya konsep yang telah dijalankan dalam program latihan tersebut. Model latihan yang digunakan adalah mengkonsep diri sebelum melakukan praktek langsung melalui wawancara, pengisian angket. Hasil yang didapatkan: (1) terdapat pengaruh yang berarti latihan tendangan kaki bagian luar terhadap akurasi tendangan bebas 30 meter, artinya Hal ini berarti semakin rutin dan sering intensitas latihannya maka akan menghasilkan tendangan bebas 30 meter yang baik dan akurat.(2) terdapat pengaruh yang berarti latihan tendangan kaki bagian dalam terhadap akurasi tendangan bebas 30 meter, artinya $\mathrm{Hal}$ ini berarti semakin rutin dan sering intensitas latihannya maka akan menghasilkan tendangan bebas 30 meter yang baik dan akurat. (3) terdapat pengaruh yang berarti latihan tendangan kaki bagian luar dan latihan tendangan kaki bagian dalam terhadap akurasi tendangan bebas 30 meter, artinya bentuk latihan ini baik latihan tendangan menggunakan kaki bagian luar ataupun dalam bisa terus di latih secara langsung maupun terprogram sesuai kebutuhan tim maka dari itu peran pelatih/pembimbing sangat berperan dalam mengasah kemahiran anak didiknya.
\end{abstract}

Kata Kunci: Latihan tendangan kaki bagian luar, latihan tendangan kaki bagian dalam, akurasi tendangan bebas 30 meter

\begin{abstract}
The purpose of the outside foot kick training and the inside foot kick tarining on the accuracy of the 30 meter free kick to find out how big the effect is and how well the concept have been carried out in the exercise program. The training model used is self-coccept before doing direct practice through interviews, questionnaires. The result obtained are: (1) there is a significant influence on the outside kick leg training on the accuracy of the 30 meter free kick, meaning that the more routine and often the intensity of the training it will produce a good and accurate 30 meter free kick. (2) there is a significant influence on the inside kick leg training on the accuracy of the 30 meter free kick, meaning that the more routine and often the intensity of the training it will produce a good and accurate 30 meter free kick. (3) there is a significant influence on the outside kick leg training and on the outside kick leg training it will produce a good and accurate 30 meter free kick, this means that this form of training both outside and inside kicks of the foot can continue to be trained directly or programmed according to the needs of the team and therefore the role of the coach / supervisor is very instrumental in honing the skills of their student.
\end{abstract}

Keyword: Outside foot kick training and the inside foot kick training, inside foot kick training and the inside foot kick training, accuracy of the 30 meter free kick 


\section{PENDAHULUAN}

Salah satu olahraga yang banyak digemari saat ini adalah Sepak bola. Sepak bola menjadi olahraga yang sangat populer di masyarakat. Semua orang bisa melalukan olahraga tersebut karena dalam memainkannya tidak membutuhkan biaya yang mahal. Peraturan sepak bola mudah diterapkan dan bahkan bisa dimodifikasi sesuai kondisi. Di indonesia olahraga sepakbola sudah dikenal berpuluh-puluh tahun, tetapi belum mampu bersaing di tingkat dunia. Menurut (Luxbacher 1991) lebih dari 200 juta orang di seluruh kawasan dunia memainkan permainan sepakbola.

Bermain sepakbola menurut Luxbacher (Luxbacher, 1999 : 2) adalah pertandingan sepak bola itu dimainkan oleh dua tim yang masing-masing beranggotakan 11 orang. Masing-masing tim mempertahankan gawan dan berusaha menjebol gawang lawan.

Sucipto (Sucipto 2000) menyatakan bahwa teknik dasar yang diperlukan dimiliki pemain sepakbola adalah menendang (kicking), menghentikan (stopping), menggiring (dribbling), menyundul (heading), merampas (tackling), lemparan ke dalam (throw-in) dan penjaga gawang (goal keeping). Setiap individu harus meningkatkan kualitas dirinya, dalam hal ini adalah kualitas fisik yang harus dikembangkan secara terus menerus. Kualitas fisik seseorang dapat berkembang jika diiringi aktivitas.

Sucipto (Sucipto 2000) Menendang bola adalah gerakan kaki untuk menyentuh, mendorong atau menyepak bola, menendang merupakan ciri khas yang paling dominan dalam permainan sepak bola. Agar dapat menjadi pemain sepak bola yang baik, seorang pemain perlu mengembangkan kemahirannya dalam menendang bola. Tujuan menendang bola adalah untuk mengumpan, menembak kegawang lawan agar teradi gol atau untuk menyapu / menghalau dalam mematahkan serangan lawan. Gerakan dasar menendang bola terdiri atas: pengambilan awalan, ayunan kaki ke belakang, saat kaki kontak dengan bola dan gerakan lanjutan setelah menendang.

Tahapan menendang bola menggunakan kaki bagian luar sebagai berikut; Tahap Persiapan; (1) Dekati bola dari belakang pada sudut yang tipis (2) letakan kaki yang menahan keseimbangan disamping bola (3) arahkan kaki ke target (4) bahu dan pinggul agak menyamping dari target (5) Tarik kaki yang akan menendang bola (6) bagian sisi luar kaki dibengkokan sedikit kea rah samping luar dan engkel dikunci (7) tangan direntangkan untuk menjaga keseimbangan (8) fokuskan perhatian kea rah bola. Tahap pelaksanaan; (1) pindahkan berat badan ke depan (2) kaki yang akan menendang diayun ke depan samping luar (3) jaga kaki agar tetap lurus (4) tendang bola menggunakan sisi kaki bagian luar. Tahap akhiran; (1) lanjutkan gerakan searah dengan bola (2) berat badan pada kaki yag menahan keseimbangan (3) gerakan kaki sejajar dengan dada. (Luxbacher 1999)

Tahapan menendang bola menggunakan kaki bagian dalam sebagai berikut: Tahap Persiapan: (1) Berdiri menghadap target (2) Letakan kaki tumpu untuk menjaga keseimbangan disamping bola (3) Arahkan kaki ayun ke target (4) Bahu dan pinggul lurus dengan target (5) Tekuk sedikit kaki ayun (6) Ayunkan kaki yang akan menendang (7) Tempatkan kaki dalam posisi menyamping (8) Tangan direntangkan untuk menjaga keseimbangan (9) Kepala tidak bergerak (10) fokus pada perkenaan kaki dengan bola. Tahap pelaksanaan: (1) Tubuh berada di atas bola (2) Ayunkan kaki yang akan menendang (3) Jaga kaki agar tetap lurus (4) Tendang bagian tengah bola dengan bagian samping dalam kaki. Tahap akhir: (1) Pindahkan berat badan kedepan (2) Lanjutkan gerakan searah dengan bola (3) Gerakan ahkir berlangsung dengan mulus (Luxbacher 1999).

Bagian bola yang ditendang sangat berpengaruh terhadap arah dan hasil tendangan. Bagian bola yang di tendang menurut (Scheunemann 2008) 
yaitu; (a) Bagian dalam kaki yang menedang tepat mengenai tengah - tengah bola, bola berguir datar di atas tanah. (b) Bagian dalam kaki yang menendang mengenai dibawah tengah - tengah bola, hasilnya bola akan naik melambung rendah.

Bola yang datang dari arah dimana pemain sedang menghadap sangat mudah untuk dilihat dan dikontrol, apalagi jika bola di operkan melalui sudut tendangan rendah. Hal ini dikarenakan bola benar - benar terlihat sepenuh waktu dan arah dari operan yang berasal dari sebuah tendangan yang mudah (Nugraha 2008).

Tendangan bebas (Free Kick) sangat krusial dalam suatu pertandingan sepak bola, terlebih apabila tim tersebut memiliki seoarang eksekutor tendangan bebas yang sempurna dan mematikan.

Situasi tersebut merupakan sebuah kesempatan untuk menciptakan gol yang harus bias dimanfaatkan semaksimal mungkin, hal yang mungkin terjadi tim akan memenangkan pertandingan. Timo dalam 14 Ciri Sepak Bola Modern menegaskan "Situasi standar (free kick) semakin penting perannya di era sepak bola modern yang begitu kompetitif seperti sekarang ini karena kualitas antar tim secara keseluruhan hampir sama" Oleh karena itu, setiap kesempatan bola mati betul - betul dipergunakan sebaik mungkin guna memenangkan pertandingan yang sebenarnya berlangsung cukup seimbang.

Tendangan bebas (free kick) adalah tendangan yang diperoleh ketika tim lawan melakukan pelanggaran. Tendangan bebas ini merupakan hadiah dari pelanggaran yang telah dilakukan oleh tim lawan, Sucipto (Sucipto 2000).

Tendangan bebas boleh dilakukan pada titik mana saja selama tidak di kotak pinalti. Apabila terlalu dekat dengan gawang lawan, biasanya dilakukan kurang lebih 9 meter bebas halangan dari tim lawan. Dimana tim lawan hanya boleh menghadang bola dengan berdiri kurang lebih 9 meter dan berjejer 3 samapai 5 orang. Posisi pagar hidup ini adalah saling berdempetan dan tangan menutup dada dan organ vital lainnya. Jenis jenis tendangan bebas (free kick); (1) tendangan bebas jarak jauh, (2) tendangan bebas jarak dekat.

Menurut aturan sepak bola FIFA pasal 13, tendangan bebas terbagi dua, yakni tendangan bebas langsung dan tendangan bebas tidak langsung. Dua tendangan tersebut terbagi berdasarkan zona pelanggaran yang terjadi. Mudahnya, saat pemain dapat mengeksekusi tendangan bebas langsung ke gawang lawan, maka itu disebut tendangan bebas langsung.

Latihan adalah proses yang sistematis dari berlatih yang dilakukan secara berulang - ulang dengan kian hari kian menambah jumlah beban latihan serta intensitas latihannya. (Harsono, 1988:126). Oleh karena itu prinsip individual merupakan salah satu syarat penting dalam latihan kontemporer dengan konsep latihan haruslah disusun sesuai dengan kekhasan setiap imdividu agar tujuan latihan dapat tercapai sejauh mungkin. Dijelaskan dalam (Bompa and Buzzichelli 2018) kemampuan usaha atlet tergantung dari beberapa faktor, diantaranya: (1) Usia biologis dan kronologis atlet. (2) Pengalaman dalam melakukan olahraga. (3) Kemampuan kerja. (4) Status kesehatan. (5) Jadwal kegiatan diluar latihan. Oleh karena itulah latihan akan menjadi suatu persoalan bagi pelatih/pembimbing atlet maka dari itu latihan harus direncanakan dan disesuaikan bagi setiap individu agar dengan demikian latihan tersebut dapat menghasilkan hasil yang terbaik (the best result) bagi setiap individu. Agar prinsip latihan bisa dilaksanakan dimana latihan harus benar - benar tercapai maka atlet harus pula disiapkan sebelumnya dalam hal ini pra-latihan (warming up). Karvonen (1957), Dalam bukunya Coaching, (Harsono, 1988) menjelaskan untuk mengukur intensitas latihan dengan tujuan untuk mengukur denyut jantung. Senada yang dijelaskan oleh Hadisasmita, 
Yusuf, dan Syarifudin (1996:153), intensitas latihan dapat diukur dengan cara denyut nadi maksimal (DNM) dengan rumus Denyut Nadi Maksimal (DNM) = 220 - umur, kemudian ditentukan takaran intensitas latihannya yaitu $80 \%-90 \%$ dari DNM. Untuk olahraga kesahatan cukup $70 \%$ - 35\% dari DNM. Latihan yang intensif belum tentu dengan sendirinya berarti bahwa latihan tersebut bermutu. Latihan yang bermutu adalah apabila latihan dan drill - drill yang diberikan memang benar - benar sesuai dengan kebutuhan atlet. (Harsono, 1988:118).

Kegiatan ekstrakurikuler adalah kegiatan tambahan, di luar struktur program yang pada umumnya merupakan kegiatan pilihan. Salah satu kegiatan ekstrakurikuler yang sangat diminati oleh siswa adalah kegiatan ekstrakurikuler olahraga.

Melalui kegiatan ekstrakurikuler olahraga disamping siswa memperdalam dan memperluas pengetahuan juga dapat dimanfaatkan sebagai upaya untuk melakukan pembinaan, pemantapan, dan pembentukan nilai -nilai kepribadian siswa, yang meliputi: kerjasama, saling menghargai, sportivitas, semangat dan percaya diri.

Ditegaskan dalam UU Republik Indonesia No.3 tahun 2005 Tentang Sistem Keolahragaan Nasional, olahraga prestasi adalah olahraga yang membina dan mengembangkan olahragawan secara terencana, berjenjang, dan berkelanjutan melalui kompetisi untuk mencapai prestasi dengan dukungan ilmu pengetahuan dan teknologi keolahragaan.

Prestasi hanya akan dapat dicapai dengan latihan-latihan yang direncanakan dan dengan sistematis dilakukan secara terus menerus yang disertai pengawasan dan bimbingan pelatih yang professional.

Maka dari itu perlu adanya upaya sinergi dari semua pihak dalam merealisasikan tujuan dari olahraga prestasi agar siswa dapat menggapai prestasi puncak di sekolah.

Olahraga prestasi dalam hal ini kegiatan ekstrakulikuler sepak bola dimana pemain dituntut menguasai teknik, taktik, dan strategi yang benar serta konsisten atas dasar koordinasi kaki untuk tetap menguasai bola untuk mendukung tercapainya tujuan dalam permainan sepak bola yaitu membuat gol ke gawang lawan dan mencegah bola masuk ke gawang sendiri.

Berprinsip kepada teori sepak bola modern saat ini bahwa perolehan gol tidak hanya sebatas kepada bola hidup dimana hasil kerjasama, teknik individual dihasilkan akan tetapi dalam permainan, situasi bola mati berperan dalam proses terjadinya gol dimana situasi bola mati salah satunya adalah tendangan bebas (free kick).

Seorang penendang free kick dituntut memiliki teknik dasar sepak bola yang baik, terutama dalam hal menendang atau menembak bola ke sasaran karena akan menentukan berhasil atau tidaknya tendangan bebas tersebut.

Berdasarkan fakta dilapangan, seperti yang terjadi pada siswa yang mengikuti ekstrakurikuler sepak bola SMP Negeri 3 Luragung, banyak siswa yang memiliki kemampuan teknik menendang yang berbeda - beda terutama dalam penggunaan kakinya.

Maka untuk meningkatkan hasil yang baik teknik menendang free kick dalam sepak bola dibutuhkan latihan yang tepat untuk siswa yang mengikuti ekstrakurikuler sepak bola di SMP Negeri 3 Luragung. Berdasarkan hal tersebut, maka penulis tertarik untuk meneliti lebih lanjut tentang "Pengaruh latihan tendangan kaki bagian luar dan latihan tendangan kaki bagian dalam terhadap akurasi tendangan bebas 30 meter pada siswa putra ekstrakurikuler sepak bola putra di SMP Negeri 3 Luragung".

\section{BAHAN DAN METODE/ METODOLOGI}

Penelitian ini dilakukan di Ekstrakulikuler SMP Negeri 3 Luragung dengan jumlah populasi 30 orang. Adapun untuk menentukan besarnya sampel menurut Arikunto (2010:116), apabila 
jumlahnya kurang dari 100 lebih baik di ambil semua. Berdasarkan jumlah peserta ekstrakurikuler hanya 30 siswa maka peneliti akan menggunakan teknik total sampling dimana pengambilan peserta sampel dari populasi dilakukan semua sampel sebanyak 30 siswa putra yang mengikuti ekstrakurikuler sepak bola di SMP Negeri 3 Luragung. Metode yang digunakan dalam penelitian ini adalah metode eksperimen. Desain penelitian yang digunakan "Pre test dan Pos tes" dengan gambaran desain penelitian eksperimen sebagai berikut:

$\mathrm{X} 1$
$\mathrm{x} 2$

Keterangan:

$$
\begin{array}{lll}
\mathrm{P} & = & \text { Populasi } \\
\mathrm{R} & = & \text { Random } \\
\text { Pre } & = & \text { Tes awal Akurasi Tendangan } \\
\text { test } & & \text { Bebas } 30 \text { meter } \\
\mathrm{OP} & = & \text { Ordinal Pairing } \\
\mathrm{X} 1= & \text { Kelompok 1 (latihan } \\
\mathrm{X} 2= & \text { tendangan kaki bagian luar) } \\
& \text { Kelompok 2 (latihan } \\
& \text { tendangan kaki bagian dalam) } \\
\text { Pos }= & \text { Tes akhir Akurasi Tendangan } \\
\text { test } & \text { Bebas 30 meter }
\end{array}
$$

Pembagian kelompok eksperimen didasarkan hasil akurasi tenangan bebas 30 meter,dimana tes awal diranking kemudian subjek yang memiliki kemampuan setara dipasang - pasangkan dalam kelompok 1 dan kelompok 2 . Dengan demikian kedua kelompok tersebut sebelum diberi perlakuan memiliki kemampuan yang sama. Pemberian perlakuan (treatment) pada penelitian yang dilakukan pada penelitian ini adalah pemberian latihan kurang lebih 16 kali pertemuan, karena menurut (Harsono 1988) bahwa latihan sesuai dengan batasan waktu minimal latihan yaitu 16 kali latihan dengan jadwal Bulan
Mei - Juli 2019. Untuk mengolah data hasil tes awal (pretest) dan tes akhir (posttest) dalam penelitian ini, maka digunakan langkah-langkah sebagai berikut :

Instrumen Penelitian yang akan digunakan dalam penelitian ini adalah tes akurasi tendangan bebas 30 meter dengan alat yang digunakan:
1. Bola kaki
2. Kun
3. Alat ukur
4. Tali
5. Peluit
6. Alat tolic

Pelaksa

Pemain P-R-Sampel-Pre testt-OP -

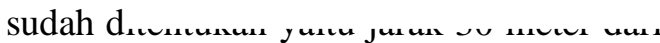
gawang dengan ditambahkan rintangan berupa pagar hidup berjarak 9 meter dari penendang.

Penendang disediakan 5 bola untuk menendang sasaran ke gawang dimana gawang telah diberi tanda untuk skor 1,3 dan 5 sebagai sasaran tendangan. Jumlah skor di akumulasikan sesuai hasil tendangan dan bola yang melenceng tidak mendapatkan skor.

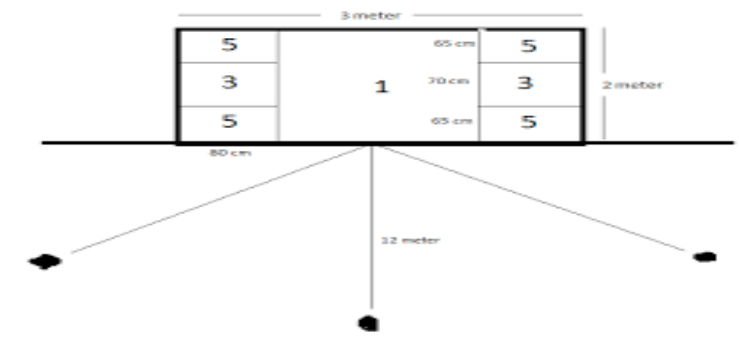

Instrumen Sasaran Tendangan Bebas Sumber: (Indianto, Suranto, and Jubaedi 2018)

\section{HASIL DAN PEMBAHASAN}

Analisis data atau pengolahan data merupakan suatu langkah penting dalam suatu penelitian. Menurut (Yani n.d.), dalam suatu penelitian kuantitatif menggunakan statistik. Statistik meliputi statistik parametris dan non parametris.

Statistik parametris digunakan untuk menganalisis data interval, rasio, jumlah sampel besar, srta berlandaskan 
bahwa data yang akan dianalisis berdistribusi normal. Sedangkan statistik non parametris digunakan untuk menganalisis data yang berbentuk nominal dan ordinal, jumlah sampel kecil dan tidak harus berdistribusi normal.

Data yang dinilai adalah variable bebas: latihan tendangan kaki bagian luar $\left(\mathrm{X}_{1}\right)$, dan latihan tendangan kaki bagian dalam $\left(\mathrm{X}_{2}\right)$ serta variabel terikat yaitu akurasi tendangan bebas 30 meter (Y).

\section{Uji Normalitas}

Tujuan uji normalitas adalah untuk mengetahui apakah distribusi yang terjadi atau tidak dari distribusi normal. Langkah sebelum melakukan pengujian hipotesis lebih dahulu dilakukan uji persyaratan analisis dengan uji naormalitas yaitu menggunakan uji liliefors, dengan langkah - langkah sebagai berikut:

a. Pengamatan $\mathrm{X}_{1}, \quad \mathrm{X}_{2} \quad \ldots . . \mathrm{Xn}$ dijadikan bilangan baku $\mathrm{Z}_{1}$, $\mathrm{Z}_{2} \ldots . \mathrm{Zn}$

b. Untuk tiap bilangan baku akan menggunakan daftar distribusi normal baku, kemudian menghitung peluang $\mathrm{F}(\mathrm{Zi})$

c. Selanjutnya menghitung proporsi $\mathrm{Z}_{1}, \mathrm{Z}_{2} \ldots \mathrm{Zn}$ yang lebih atau sama dengan $\mathrm{Zi}$.

d. Ambil harga yang paling besar diantara harga - harga mutlak selisih tersebut. Sebutlah harga sebesar $\mathrm{L}_{0}$.

e. Kriteria pengujian adalah jika Lhitung Ltabel, maka variabel tersebut

berdistribusi normal, sedangkan jika Lhitung Ltabel maka variabel berdistribusi tidak normal

\section{Uji Homogenitas}

Uji homogenitas dilakukan untuk memperoleh informasi apakah kedua kelompok sampel memeliki varian yang homogen atau tidak. Untuk pengujian homogenitas digunakan rumus sebagai berikut:

$F=\frac{\text { Varians Terbesar }}{\text { Varians Terkecil }}$
Membandingkan $\mathrm{F}$ hitung dengan $\mathrm{F}$ tabel dengan rumus:

Dk pembilang : n-1 (untuk varians terbesar)

Dk penyebut: $\mathrm{n}-1$ (untuk varians terkecil) Taraf signifikansi 0,05 maka dicari pada table $\mathrm{F}$, dengan kriteria pengujian:

Jika : F hitung

\section{$\geq$ F Tabel Tidak Homogen}

$$
\text { F hitung }
$$

\section{$\leq \mathrm{F}$ Tabel Berarti Homogen}

Pengujian homogenitas ini bila $\mathrm{F}$ hitung lebih kecil $(<)$ dari $\mathrm{F}$ table maka data tersebut mempunyai varians yang homogeny. Tapi sebaliknya bila F (>) dari $\mathrm{F}$ table maka kedua kelompok mempunyai varians yang sama.

\section{Uji Hipotesis}

Analisis dilakukan untuk menguji hipotesis yang telah dilakukan, yaitu untuk mengetahui besarnya konribusi yang diberikan oleh variable bebas $(\mathrm{X})$ terhadap variable terikat $(Y)$. Sugiyono $(2015: 273)$ "bila sampel berkorelasi/berpasangan, misalnya membandingkan sebelum dan sesudah treatment atau perlakuan, atau membandingkan kelompok control dengan kelompok eksperimen, maka digunakan ttes". Dengan rumus t-test sebagai berikut:

a. Bila jumlah anggota sampel $\mathrm{n} 1=$ $\mathrm{n} 2$, dan varian homogen $\left(\sigma_{1=} \sigma_{2}\right)$, maka dapat digunakan rumus t-test baik untuk sepaerated maupun pool varians.

b. Bila $\mathrm{n} 1 \neq \mathrm{n} 2, \quad$ varian homogen $\left(\sigma_{1=} \sigma_{2}\right), \quad$ dapat digunakan rumus t-tes pool varian.

c. Bila $\mathrm{n} 1=\mathrm{n} 2$, varian tidak homogeny $\left(\sigma_{1} \neq \sigma_{2}\right), \quad$ dapat digunakan rumus sepaerated varians atau pooled varian dengan $\mathrm{dk}=\mathrm{n} 1-1$ atau $\mathrm{n} 2-1$

d. Bila $\mathrm{n} 1 \neq \mathrm{n} 2$ dan varian tidak

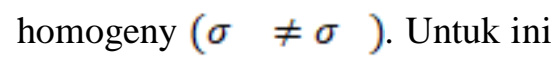
menggunakan t-tes dengan separated varians. Harga t sebagai ganti t- table dihitung dari selisih harga t-tabel dengan dk (n1-1) dan dk (n2-1) dibagi dua, kemudian 
ditambahkan dengan harga $t$ yang terkecil.

e. Ketentuannya bila t-hitung $\leq t$-tabel, maka $\mathrm{H}_{0}$ diterima dan tolak Ha.

Hasil Uji Validitas Instrument Variabel Latihan Tendangan Kaki Bagian Luar

Instrument penelitian yang digunakan untuk pengumpulan data sebanyak 25 pernyataan. Setelah dilakukan uji validitas ternyata yang valid sebanyak 22 item pernyataan.

\section{Hasil Uji Validitas Instrument Variabel Latihan Tendangan Kaki Bagian Dalam}

Instrument penelitian yang digunakan untuk pengumpulan data sebanyak 25 pernyataan. Setelah dilakukan uji validitas ternyata yang valid sebanyak 22 item pernyataan.

Berikut hasil uji validitas variabel latihan tendangan kaki bagian dalam bisa dilihat pada tabel dibawah:

\section{Hasil Uji Validitas Instrument Variabel Akurasi Tendangan Bebas 30 meter}

Instrument penelitian yang digunakan untuk pengumpulan data sebanyak 25 pernyataan. Setelah dilakukan uji validitas ternyata yang valid sebanyak 23 item pernyataan.

Berikut hasil uji validitas variabel akurasi tendngan bebas 30 meter bisa dilihat pada tabel dibawah:

\section{Uji Reliabilitas}

Uji reliabilitas dilakukan untuk memastikan apakah instrumen yang dipakai reliabel atau tidak, maksud dari reliabel adalah jika instrumen tersebut diujikan berulang-ulang maka hasilnya akan sama. Untuk pengujian reliabilitas digunakan teknik Alpha Cronbach,

\section{Hasil Uji Reliabilitas Latihan Tendangan Kaki Bagian Luar}

Sementara itu dari hasil perhitungan reliabilitas instrument menunjukan nilai $\alpha$ (Alpha) sebesar 0,959, dan bila dibandingkan dengan $r$ tabel pada tingkat kepercayaan $95 \%$ yakni sebesar 0,361 , berarti instrument untuk mengukur variabel $\mathrm{X}_{1}$ adalah reliable karena ( $\mathrm{r}$ hitung $0,959>0,361\left(r_{\text {tabel }}\right)$.

\section{Hasil Uji Reliabilitas Latihan Tendangan Kaki Bagian Dalam}

Sementara itu dari hasil perhitungan reliabilitas instrument menunjukan nilai $\alpha$ (Alpha) sebesar 0,804, dan bila dibandingkan dengan $r$ tabel pada tingkat kepercayaan $95 \%$ yakni sebesar 0,361, berarti instrument untuk mengukur variabel $\mathrm{X}_{2}$ adalah reliable karena ( $\left.\mathrm{r}_{\text {hitung }}\right)$ $0,804>0,361\left(r_{\text {tabel }}\right)$.

\section{Hasil Uji Reliabilitas Akurasi \\ Tendangan Bebas 30 meter}

Sementara itu hasil dari perhitungan reliabilitas instrument menunjukan nilai $\alpha$ (Alpha) sebesar 0,939, dan bila dibandingkan dengan $r_{\text {tabel }}$ pada tingkat kepercayaan $95 \%$ yakni sebesar 0,361, berarti instrument untuk mengukur variabel $\mathrm{X}_{1}$ adalah reliable karena ( $\mathrm{r}_{\text {hitung }}$ ) $0,939>0,361\left(\mathrm{r}_{\text {tabel }}\right)$.

\section{Uji Signifikansi}

Uji signifikansi dimaksudkan untuk melihat kebermaknaan atau derajat hubungan antar variabel $X_{1}$ terhadap variabel $\mathrm{Y}$, maupun variabel $\mathrm{X}_{2}$ terhadap Y maka hasil korelasi PPM tersebut diuji dengan uji signifikansi dengan menggunakan uji- $t$

Hasil penghitungan $t_{\text {hitung }}$ kemudian dibandingkan dengan harga $t_{\text {tabel. }}$. Apabila $t_{\text {hitung }}$ lebih besar dari $t_{\text {tabel }}$, maka terdapat hubungan yang linier. Dengan demikian butir item dianggap valid, dan apabila harga $t_{\text {hitung }}$ lebih kecil dari harga $t_{\text {tabel }}$ maka tidak terdapat hubungan yang linier. Dengan demikian butir item dinyatakan valid.

Jika instrument tersebut valid sesuai dengan kriteria indeks validitas korelasi sebagai berikut:
Antara $0,800 \mathrm{~s} / \mathrm{d} 1,000=$ sangat tinggi
Antara $0,600 \mathrm{~s} / \mathrm{d}$ 0,799 = tinggi
Antara 0,400 s/d 1,599= cukup 
Antara 0,200 s/d 1,399 = rendah

Antara 0,000 s/d 1,999= sangat rendah

(Riduan, 2010:74)

\section{Uji Multikolonieritas}

Uji multikolinearitas dilakukan untuk mengetahui ada atau tidaknya penyimpangan asumsi klasik multikolonieritas yaitu adanya hubungan liniear antar variabel independen dalam model regresi. Dengan menggunakan nilai variance inflation factor (VIF) atau tolerance. Model dinyatakan terbebas dari gangguan multikolinearitas jika mempunyai nilai VIF di bawah 10 atau tolerance di atas 0,1 . Uji Multikolonieritas ini menggunakan program SPSS 21.

\section{Uji Heteroskedastisitas}

Dalam penelitian ini uji heteroskedastisitas dilakukan dengan tujuan untuk mengetahui ada tidaknya pola tertentu pada grafik scatterplot antara SRESID dengan ZPRED adalah sumbu Y dimana sumbu Y yang telah diprediksi dan sumbu $\mathrm{X}$ adalah residual. Kriteria unutk menjawab hipotesis sebagai berikut:

$\mathrm{H}_{0}$ : tidak ada gejala heteroskedastisitas apabila tidak ada pola yang jelas, seperti titik-titik menyebar di atas dan di bawah angka 0 pada sumbu Y.

$\mathrm{H}_{\mathrm{a}}$ : ada gejala heteroskedastisitas apabila ada pola tertentu yang jelas, seperti titiktitik membentuk pola tertentu yang teratur (bergelombang, melebar kemudian menyempit).

\section{Uji Autokorelasi}

Model regresi yang baik adalah regresi yang bebas dari autokorelasi. Ada beberapa cara yang dapat digunakan untuk mendeteksi ada atau tidaknya autokorelasi. Dalam penelitan ini akan menggunakan Uji Autokorelasi dengan Durbin Watson (DW test).

Tujuan uji autokorelasi untuk menguji apakah dalam model regresi linear ada korelasi antara kesalahan pengganggu pada periode $t$ dengan kesalahan pada periode $t 1$ (sebelumnya).
Metode pengujian yang sering digunakan adalah dengan uji Durbin-Watson (uji DW) dengan ketentuan sebagai berikut : Jika d lebih kecil dari dL atau lebih besar dari (4-dL) maka hopotesis nol ditolak, yang berarti terdapat autokorelasi.

Jika d terletak antara dU dan (4-dU), maka hipotesis nol diterima, yang berarti tidak ada autokorelasi.

Jika d terletak antara dL dan dU atau diantara (4-dU) dan (4-dL), maka tidak menghasilkan kesimpulan yang pasti.

\section{Uji Goodness of Fit}

Uji goodness of fit adalah untuk melihat kesesuaian model, atau seberapa besar kemampuan variabel bebas dalam menjelaskan varians variabel terikatnya. Langkah-langkah pengujian hipotesis goodness of fit sebagai berikut:

a. Menentukan hipotesis

HO : frekuensi pengamatan sesuai dengan frekuensi yang diharapkan

H1 : frekuensi pengamatan tidak sesuai dengan frekuensi yang diharapkan

b. Menentukan tingkat signifikansi $(\alpha)$ dan nilai X2 tabel ditentukan dengan derajat bebas $(\mathrm{db})=\mathrm{k}-\mathrm{N}$,

c. Membuat kesimpulan

Menyimpulkan apakah $\mathrm{H}_{0}$ ditolak atau diterima berdasarkan nilai statisitik uji yang diperoleh. Uji goodness of fit menggunakan program SPSS 21.

\section{Uji t (parsial)}

Uji $\mathrm{t}$ (parsial) adalah untuk melihat pengaruh variabel-variabel bebas $\left(\mathrm{X}_{1}, \mathrm{X}_{2}\right)$ secara parsial (sendiri-sendiri) berpengaruh signifikan terhadap variabel terikatnya (Y). Uji ini dengan membandingkan $t_{\text {hitung }}$ dengan $t_{\text {tabel }}$ dengan signifikansi 0,05.

Dasar pengambilan keputusan:

$\mathrm{H}_{0}$ diterima dan $\mathrm{H}_{1}$ ditolak jika nilai $\mathrm{t}_{\text {hitung }}$ $<$ dari $t_{\text {tabel }}$ atau jika nilai sig. $>$ dari 0,05

$\mathrm{H}_{0}$ ditolak dan $\mathrm{H}_{1}$ diterima jika nilai $\mathrm{t}_{\text {hitung }}$ $>$ dari $t_{\text {tabel }}$ atau jika nilai sig. $<$ dari 0,05 Untuk pengujian ini menggunakan program SPSS 21. 


\section{Uji F ANOVA}

Uji $F$ digunakan untuk mengetahui pengaruh variabel bebas secara bersamasama (simultan) terhadap variabel terikat. Signifikan berarti hubungan yang terjadi dapat berlaku untuk populasi.

Uji $F$ dilakukan dengan membandingkan $\mathrm{F}_{\text {hitung }}$ dengan $\mathrm{F}_{\text {tabel. }}$ Jika $\mathrm{F}_{\text {hitung }}>$ dari $\mathrm{F}_{\text {tabel }}$, $\left(\mathrm{H}_{0}\right.$ ditolak $\mathrm{Ha}$ diterima $)$ dan $\mathrm{F}_{\text {hitung }}$ dengan $\mathrm{F}_{\text {tabel. }}$ Jika $\mathrm{F}_{\text {hitung }}<$ dari $\mathrm{F}_{\text {tabel }}$ maka model tidak signifikan. Pengujian untuk Uji F menggunakan program SPSS

Model diagram jalur dibuat berdasarkan variabel-variabel yang dikaji, dalam penelitian ini variabel yang dikaji adalah latihan tendangan kaki bagian luar, latihan tendangna kaki bagian dalam, akurasi tendangan bebas 30 meter.

\section{Pengaruh Latihan Tendangan Kaki Bagian Luar Terhadap Akurasi Tendangan Bebas 30 meter}

Berdasarkan hasil penelitian dapat dijelaskan bahwa terdapat pengaruh yang berarti latihan tendangan kaki bagian luar terhadap tendangan bebas 30 meter SMP Negeri 3 Luragug. Hal ini berarti semakin rutin dan sering intensitas latihannya maka akan menghasilkan tendangan bebas 30 meter yang baik dan akurat.

Peningkatan kualitas repitisi latihan tendangan bebas 30 meter akan sangat memberikan dampak positif terhadap prestasi non akademik dalam bidang olahraga khususnya kegiatan ekstrakurikuler sepak bola yang dilakukan oleh siswa.

\section{Pengaruh Latihan Tendangan Kaki Bagian Dalam Terhadap Akurasi Tendangan Bebas 30 meter}

Berdasarkan hasil penelitian dapat dijelaskan bahwa terdapat pengaruh yang berarti latihan tendangan kaki bagian dalam terhadap tendangan bebas 30 meter SMP Negeri 3 Luragug. Hal ini berarti semakin rutin dan sering intensitas latihannya maka akan menghasilkan tendangan bebas 30 meter yang baik dan akurat.
Peningkatan kualitas repitisi latihan tendangan bebas 30 meter akan sangat memberikan dampak positif terhadap prestasi non akademik dalam bidang olahraga khususnya kegiatan ekstrakurikuler sepak bola yang dilakukan oleh siswa.

Pengaruh Latihan Tendangan Kaki Bagian Luar dan Latihan Tendangan Kaki Bagian Dalam Terhadap Akurasi Tendangan Bebas 30 meter

Berdasarkan hasil penelitian dapat dijelaskan bahwa terdapat pengaruh yang berarti latihan tendangan kaki bagian luar dan latihan tendangan kaki bagian dalam terhadap akurasi tendangan bebas 30 meter SMP Negeri 3 Luragung.

Kedua bentuk latihan ini baik latihan tendangan menggunakan kaki bagian luar ataupun dalam, bisa terus di latih secara langsung maupun terprogram sesuai kebutuhan tim maka dari itu peran pelatih/pembimbing sangat berperan dalam mengasah kemahiran anak didiknya.

\section{KESIMPULAN DAN SARAN}

Berdasarkan hasil kajian dan pembahasan penelitian yang telah penulis laksanakan mengenai pengaruh latihan tendangan kaki bagian luar dan latihan tendangan kaki bagian dalam terhadap akurasi tendangan bebas 30 meter SMP Negeri 3 Luragung, penulis dapat menarik simpulan sebagai berikut:

1. Latihan tendangan kaki bagian luar berpengaruh positif terhadap akurasi tendangan bebas 30 meter dengan nilai $\mathrm{t}_{\text {hitung }} 3,658>\mathrm{t}_{\text {tabel }}$ 1,703 dengan nilai signifikansi (sig) $0,01<0,05$ dapat disimpulkan bahwa $\mathrm{H}_{1}$ diterima dan $\mathrm{H}_{0}$ ditolak yang artinya latihan tendangan kaki bagian luar dalam kategori baik, jika latihan tendangan kaki bagian luar baik maka akurasi tendangan bebas 30 meter akan baik pula. Latihan tendangan kaki bagian luar yang dijalankan dan terprogram sudah 
mampu menjawab kebutuhan keinginan pelatih dan kebutuhan tim dalam sepak bola modern saat ini, karena perolehan gol tidak selalu dihasilkan secara teknis ketika play off akan tetapi dalam situasi tertentu dalam hal ini bola mati (free kick) semaksimal mungkin peluang ini dimanfaatkan untuk memperoleh gol.

2. Latihan tendangan kaki bagian dalam berpengaruh positif terhadap akurasi tendangan bebas 30 meter dengan nilai $t_{\text {hitung }} 1,881$ $>\mathrm{t}_{\text {tabel }} 1,703$ dan nilai signifikansi (sig) $0,04>0,05$ dapat disimpulkan bahwa $\mathrm{H}_{1}$ diterima dan $\mathrm{H}_{0}$ ditolak artinya latihan tendangan kaki bagian dalam, dalam kategori baik, jika latihan tendangan kaki bagian dalam baik maka akurasi tendangan bebas 30 meter akan baik pula. Latihan tendangan kaki bagian dalam yang dijalankan dan terprogram sudah mampu menjawab keinginan pelatih dan kebutuhan tim dalam sepak bola modern saat ini, karena perolehan gol tidak selalu dihasilkan secara teknis ketika play off akan tetapi dalam situasi tertentu dalam hal ini bola mati (free kick) semaksimal mungkin peluang ini dimanfaatkan untuk memperoleh gol.

3. Pengaruh latihan tendangan kaki bagian luar dan latihan tendangan kaki bagian dalam terhadap akurasi tendangan bebas 30 meter dengan nilai $\mathrm{F}_{\text {hitung }}$ adalah 5,373 dengan tingkat signifikan 0,209 sedangkan $\mathrm{F}_{\text {tabel }}$ pada taraf kepercayaan $95 \% \quad(0,05)$ adalah 3,35. Karena $F_{\text {hitung }}>F_{\text {tabel }}$ atau signifikansinya $0,00>0,05$ yang artinya latihan tendangan kaki bagian luar dalam kategori baik dan latihan tendangan kaki bagian dalam dalam kategori baik, jika latihan tendangan kaki bagian luar dalam kategori baik dan latihan tendangan kaki bagian dalam dalam kategori baik maka akurasi tendangan bebas 30 meter akan baik pula.

\section{Saran}

Dari seluruh uraian yang telah penulis ungkapkan dalam penelitian ini, dengan demikian penulis dapat mengemukakan saran-saran sebagai berikut:

1. Pencapaian hasil latihan yaitu akurasi tendangan bebas 30 meter secara langsung akan bersinggungan dengan kegiatan akademik maupun non akademik dan kegiatan ini merupakan studi dari kegitana non akademik yaitu kegiatan ekstrakurikuler sepak bola, maka dari itu apapun bentuk prestasi yang didapat oleh siswa harus diberi penghargaan dari sekolah karena pada dasarnya akan membawa nama baik sekolah di bidang olah raga khususnya sepak bola.

2. Runtutan jadwal kegiatan siswa yang telah diprogramkan harus selalu mendapat dukungan dari berbagai pihak dalam hal ini tidak hanya peran pelatih akan tetapi dorongan kepala sekolah dan guru - guru yang lain sangan dibutuhkan dukungannya baik moril maupun materi. Pelatih tidak hanya sekedar bisa membimbing akan tetapi disamping itu pengetahuan dalam melatih juga perlu ditingkatkan dengan cara mengikuti latihan latihan kepelatihan supaya ada perubahan dalam tim.

3. Perkembangan media harus selalu diikuti oleh pelatih karena pada prinsipnya latihan seperti drill drill yang dilaksanakan sangat membantu sekali dalam menunjang kemahiran siswa dalam mengembangkan skillnya.Penelitian selanjutnya disarankan agar peneliti dapat 
menambah variabel berpengaruh lain sehingga dapat diketahui faktor yang yang paling berpengaruh terhadap akurasi tendangan bebas 30 meter, dan perlunya penelitian ulang untuk mengetahui peningkatan akurasi tendangan bebas 30 meter setelah memperbaiki pelaksanaan latihan tendangan kaki bagian luar dan latihan tendangan kaki bagian dalam.

\section{DAFTAR PUSTAKA}

Andrianto. 2011. Pengaruh Latihan Tendangan Menggunakan Kaki Bagian Dalam Dan Punggung Kaki Terhadap Hasil Tendangan Penalti Pada Pemain PS HW Kudus.Universitas Negeri Semarang.

Arikunto, Suharsimi. 2010. "Prosedur Penelitian Suatu Pendekatan Praktik, Jakarta: Rineka Cipta, Cet." Ke-13.

Bompa, Tudor O, and Carlo Buzzichelli. 2018. Periodization-: Theory and Methodology of Training. Human kinetics.

Harsono, Coaching. 1988. "Aspek-Aspek Psikologi Dalam Coaching." Jakarta: CV Tambak Kusuma.

Indianto, Indianto, Suranto Suranto, and Ade Jubaedi. 2018. "Pengaruh Latihan Menendang Menggunakan Punggung Kaki Dan Kaki Bagian Dalam Terhadap Penalti." Jupe (Jurnal Penjaskesrek) 4(4).

Luxbacher, Joe. 1991. Teaching Soccer: Steps to Success. Human Kinetics Publishers.

1999. Attacking Soccer. Human Kinetics.

Mulyawan, Yandi. 2017. "Pengaruh Latihan Kekuatan Dan Ketepatan Terhadap Shooting Sepakbola Padasiswi Ekstrakulikuler Sepak Bola Putri Smk Swadhipa 1 Natar Tahun Ajaran 2016/2017."
Nugraha, Ubaidillah. 2008. Republik Gila Bola. Ufuk Publishing House.

Scheunemann, Timo. 2008. "Dasar-Dasar Sepakbola Modern." Malang. Penerbit Dioma.

Sucipto, Dkk. 2000. “Sepakbola.” Jakarta: Departemen Pendidikan Nasional Dirjen Dikdasmen bagian proyek penataran guru SLTP setara D III.

Sukadiyanto \& Muluk, D. 2011. "Pengantar Teori Dan Metodologi Melatih Fisik." Bandung: Lubuk Agung.

Syarifuddin, Aip, and Yusuf Hadisasmita. 1996. "Ilmu Kepelatihan Dasar." Jakarta: Proyek Pendidikan Tenaga Akademik.

Yani, Jenderal Achmad "Sugiyono.(2012). Metode Penelitian Kuantitatif, Kualitatif, Dan R\&D. Bandung: Alfabeta." 